most national employers. The areas of the highest salaries were mainly those having the prosperous engineering, shipbuilding, food-processing and chemical industries in good measure with a high proportion of export trade. It is reasonable to assume that the pattern of clerical salaries for adult male clerks followed a pattern of economic prosperity.

London comes fairly low down on the scale. Within Greater London there was only one district-the West End-where salaries were comparable with those on Merseyside. This is in contrast with the usual assumption that salaries are generally higher in London than in the rest of the country.

The pattern of variations of salaries for women clerks is simpler and more in accordance with traditional ideas. Greater London was the area of high salaries; the other conurbations had noticeably lower salaries with little to choose between them in contrast with the experience of men clerks in this area.

\title{
HELP FOR THE ARTS
}

$\mathbf{A}^{\mathrm{L}}$ LTHOUGH the full policy of the Calouste Gulbenkian Foundation of Lisbon includes the fields of science, art, education and charity, it now announces that it is prepared to implement the suggestions in a report just issued*. This means that for the next three or four years the emphasis of the activities of the Foundation in the United Kingdom will be almost exclusively in the field of the arts.

The report, prepared by a small informal committee consisting of Lord Bridges (chairman), the Countess of Albemarle, Mr. Nöel Annan and Sir George Barnes, is the result of their deliberations to help the Foundation by a review of the needs of the arts in Britain. After a few discussions in London the committee visited Bristol, Cardiff, Glasgow, Liverpool, Newcastle upon Tyne and Nottingham. Information was also supplied by a hundred local authorities and by all the universities.

Probably the most striking and indeed definite conclusion is that the arts need help in the provinces to a far greater extent than they do in London. Another point is that far greater support is needed for the arts than in the past and also that this is not a temporary need. This means that in the future public authorities will have to find more money for the arts. It is also stressed that far more needs to be done to-day to render the arts accessible, that there should be more scope for experiment in order to invigorate the arts and that more should be done to foster appreciation among the young. If as the committee believes, the Foundation can do its best service by stimulating art in the provinces it is pointed out that although under the Local Government Act of 1948 local authorities are permitted to spend up to a $6 d$. rate each year on any form of entertainment it is

* Help for the Arts : a Report to the Calouste Gulbenkian Foundation. Pp. 64. (London: Calouste Gulbenkian Foundation, United Kingdom and British Commonwealth Branch, 1959.) $3 s$. ascertained that over the whole country expenditure does not exceed $\frac{3}{4} d$. rate for museums and art galleries and $\frac{1}{5} d$. for music and drama. The members of this informal committee consider that the universities could and should do much more for the 'practice' and encouragement of the arts. Traditionally, this has been left to university societies and thus is outside the scope of the university patronage.

In discussing the specific ways in which the Foundation can help, it is stressed that it should be prepared to back individuals-and to encourage and foster new developments or growing points, feeling that eventually they will be self-supporting and attract permanent support from public funds or elsewhere.

Museums and art galleries receive much considera. tion, and although the committee welcomes the in. crease in grants recently announced it is suggested that pictures accepted by the Treasury in lieu of death duties should in certain cases pass to the provincial galleries. This involves the acceptance of pictures perhaps not of exceptional importance but of great interest to a local gallery. It is also felt that although museums have done much good work in developing school services they seem to have lagged behind the expension in other educational fields. A more active policy of loans between museums is advocated, and for this a general survey of material in the collections is essential. This also leads to the establishment of an improved conservation service. It is also suggested that the Foundation might help to buy works of art for provincial galleries.

In conclusion, the committee considers that Great Britain is producing artists of the highest quality, but adequate support or patronage is lacking. It is to be hoped that the Foundation gives a speedy implementation to the suggestions in this report and then in good time turns to the support of the sciences in Great Britain.

\section{DIETARY FACTORS IN THE HOMOGRAFT REACTION}

\author{
BY Dr. A. S. PARKES, F.R.S. \\ Division of Experimental Biology, National Institute for Medical Research, Mill Hill, London, N.W.7
}

$\mathrm{E}$ XPERIMENTS carried out in 1955 with five strains of mice maintained at this Institute showed that ovarian autografts established themselves regularly and became endocrinologically active within an average time of 10-11 days. In three of the strains intra-strain homografts behaved similarly during the four-week period of observation. In the other two strains, intra-strain ovarian homografts took and survived less well than autografts. Inter-strain ovarian grafts took moderately in some combinations, but rarely survived for four weeks ${ }^{1}$.

Repetition of some of these experiments two years later showed that there had been a marked increase in resistance to intra-strain grafts. In the three 